http://dx.doi.org/10.4314/jae.v18i1.12

\title{
Enhancing Training of Staff of the Agricultural Development Programme for Effective Agricultural Extension Service Delivery in Nigeria
}

\author{
Wahab, A. A'., Ladan, E. $0^{1}$., Adeogun, T. $F^{2}$., Baidu, A. L'., Okwori, E'. and \\ Ornan, $\mathbf{H}^{3}$
}

1. National Agricultural Extension and Research Liaison Services, Ahmadu Bello University, Zaria

2. Department of Agricultural Extension, University of Nigeria, Nsukka

3. Adamawa State Polytechnic, Yola, Adamawa State

Corresponding author: aawahab2@gmail.com Telephone: +2348054788410

\section{Abstract}

This paper, identified the areas where staff of the Agricultural Development Programme $(A D P)$ that carry out grassroots extension service delivery need to be trained and the field problems requiring research intervention. Secondary data from Annual Performance Survey (APS) report of NAERLS and NPAFS between 2010 and 2012 were used. The data were analyzed using descriptive statistics. Results showed that the most frequent key areas where trainings needed were long term course, short term refresher trainings, pre-season training, management training for administrative staff, specialized for subject matter specialist and data collection processing/analysis. The study further revealed that the development of livestock feed formula from local materials, heat-tolerant and disease resistant varieties of tomato and wheat were the most pressing problems requiring the researchers' attention. It is recommended that ADPs should be given periodic training by relevant organizations on the identified areas and researchers should focus their researches more on the identified problems requiring research intervention. Moreover, state governments should adequately sponsor trainings of ADPs in their various states. This will strengthen the ADPs skills and increase their productivities for an effective extension service delivery in Nigeria.

Key words: ADPs, capacity building, extension services.

\section{Introduction}

Generally, all organizations need to train their personnel from time to time in order to strengthen the staff's skills, increase productivity and achieve higher organizational performance (NAERLS and NPAFS, 2011), including Agricultural Development Projects (ADPs) in Nigeria. Irregular training of ADPs staff is one of challenges confronting 
agricultural extension service delivery in Nigeria. Over the years, the main hindrance to training has been shortage of funds. As a result, most of the ADPs have not been able to sustain regular training that could help them to disseminate appropriate technologies need passing across to the farmers, especially with grassroots extension delivery. NAERLS and NPAFS (2011) observed that low capacity building and shortage of fund have been parts of problems facing ADPs in Nigeria. Allo (2001) pointed out that one of the main factors limiting the development of effective training programmes for agricultural professionals in developing countries is inadequacy of information on their training needs. More so, Ayansina (2011); Haruna and Abdullahi (2013) all established that provision of staff training and development programmes are inadequate and limited to a few staff of ADPs in Nigeria.

Additionally, Sanni et al (2009) maintained that education and knowledge status of most extension staff fell short of much desired goal of bringing about rural and agricultural development through qualitative and committed extensions service. Yet this grade of extension workers constitutes the contact point between the extension service and farmers in the rural areas. Knowledge is a product of field experience and consistent training over time. These have not been forth-coming as the inability of the extension outfit to actualize such important incentives has been hinged on various reasons which hovers on inadequate funds, misplaced priority, official mismanagement and general lack of commitment and sacrifice on the part of some extension agents. The predominance of poorly trained extension staff upon whom many categories of farmers depend has not been able to achieve a great deal of success in rural development where agriculture is the major occupation.

Moreover, ADPs liaise with the research institutes for improved technologies in order to effectively deliver extension services to the farmers. The problems that emanate from agriculture at grass roots level are identified and related to the scientists for plausible solutions. The scientists then work on them to provide solutions in forms of improved technologies. These technologies are disseminated to the farmers for implementation (Ogunsumi and Abegunde, 2011). However, most often, the researchers embark on researches that are not the farmers' immediate need which make the result of such researches remain unexploited. This paper, thus, identifies the areas where ADPs with grassroots extension service delivery need to be trained in order to strengthen their capacities and identify the field problems requiring research intervention for effective extension delivery in Nigeria. Consequently, this will create a robust capacity building programme for the ADPs staff in order to be able to deliver extension services effectively.

The Objectives of the paper were to:

i. identify the training need of ADPs in Nigeria;

ii. know the problem areas where farmers need research intervention. 


\section{Methodology}

Secondary data obtained from annual reports of the National Agricultural Performance Survey (APS) conducted by the National Agricultural Extension and Research Liaison Services (NAERLS) in collaboration with the National Programme on Agriculture and Food Security (NPAFS) between 2010 and 2012 were used. Data were analyzed using frequency and percentage.

\section{Results and Discussion}

\section{Trainings Need of ADPs}

The result as shown in Table 1 indicated that all categories of ADPs staff need training in an area or the other. The most frequent area where the ADPs needed training in 2010 were Subject Matter Specialists (SMSs), fish farming technology, seed production and certification with $43 \%$ each.

In 2011, the needed trainings also covered different areas and vary considerably across the ADPs. The most needed training subject matter included: crop improvement and pests \& diseases management, pre-season, post-season and other refresher trainings and use of Computer, Web and other ICTs in agriculture. Other areas were: agricultural extension and communication methods, agricultural projects planning and management, Fisheries culture, nutrition and breeding, human resource management and office administration, participatory training techniques, and survey methods and statistical analysis. Results further showed that in 2012, the most frequent key areas where trainings needed were long term course (16\%), short term refresher trainings (32\%), pre-season training (9\%), management training for administrative staff $(50 \%)$, specialized for subject matter specialist (49\%) and data collection processing/analysis (4\%). 
Table 1: Prioritized training need of ADPs staff in Nigeria between 2010 and 2012

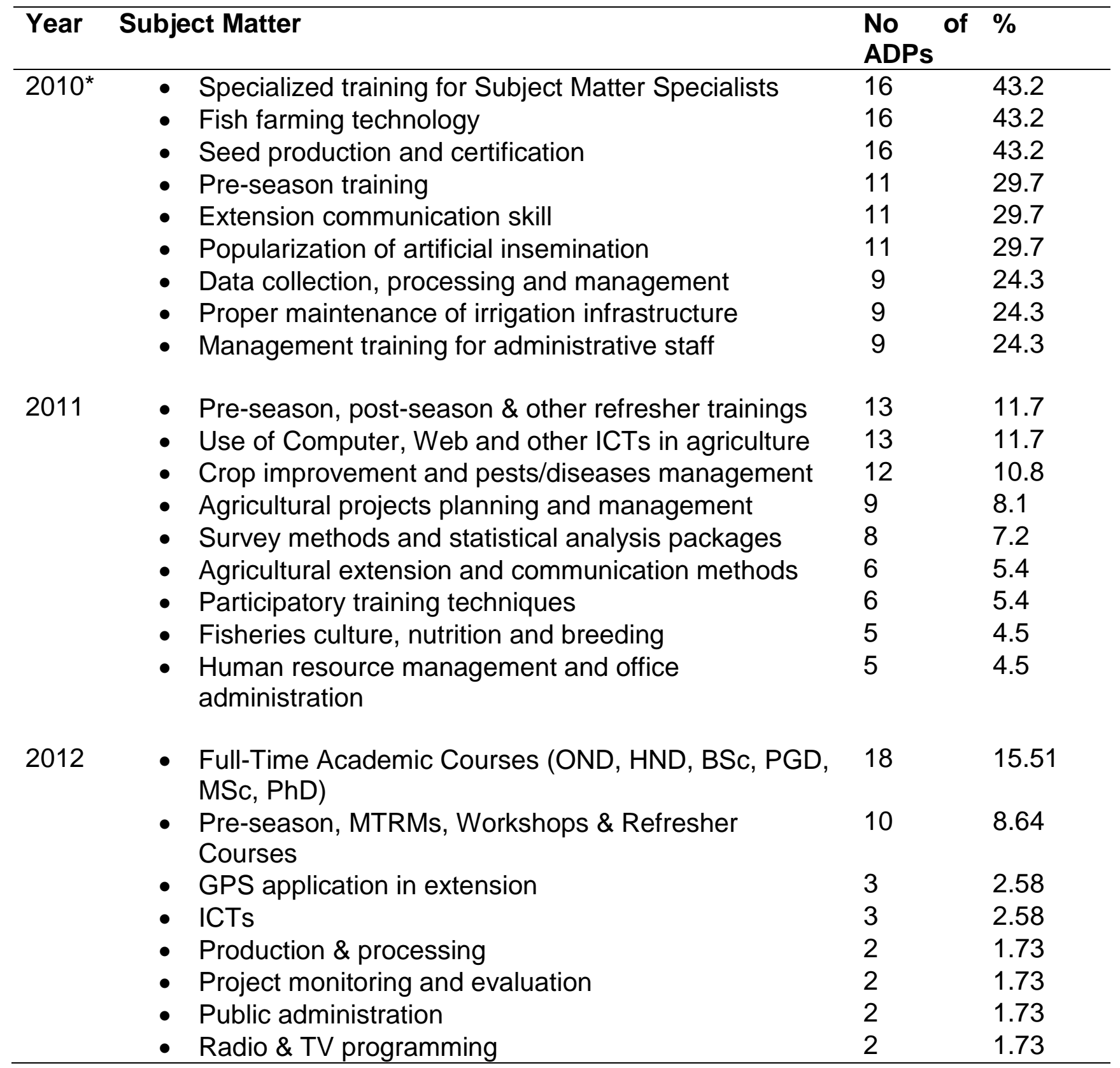

${ }^{*}$ Multiple responses

Source: NAERLS and NPAFS (2010 - 2012)

\section{Identified Problems that Needed Research Intervention between 2010 and 2012}

Tables $2-7$ showed field problems requiring research intervention between 2010 and 2012 in all the 6 geopolitical zones in Nigeria. Areas of research intervention were divided into agricultural engineering and irrigation, crop and forestry, livestock and fisheries. The problems differ from zone to zone. Development of feed formula from 
local materials, especially for poultry and fish, were ranked the most pressing problems requiring the attention of researchers in all the zones. These were followed by need for innovative heat-tolerant and disease-resistant varieties of tomato in the North East and North West. The Southern states request, heat tolerant wheat and low temperaturetolerant maize and rice varieties for irrigation farming.

Problems of premature fruit and flower abortion, dieback and other diseases of cocoyam were identified in all the zones. Low productivity of most of the varieties of crops and livestock species in use by farmers remained a problem for research. Striga infestation, high cost of production and how to secure agricultural land, especially at peri-urban sites and improving farm gate prices are major concerns of farmers.

The other problems for research are related to multipurpose tree species, crops and livestock species are adaptable to climate change, especially drought and resistant to pests and diseases. More so, farmers want research to produce commercialized process of upgrading local crops for advanced saleable product development of new commercializable products from local crops. 
Table 2: North East problems that need research intervention between 2010 and 2012

\begin{tabular}{|c|c|c|c|c|}
\hline Year & $\begin{array}{l}\text { Agric Engineering } \\
\text { and Irrigation }\end{array}$ & Crop and Forestry & Livestock & Fisheries \\
\hline \multirow[t]{2}{*}{2010} & $\begin{array}{l}\text { Development of } \\
\text { indigenous combine } \\
\text { harvester }\end{array}$ & $\begin{array}{l}\text { Intercropping of } \\
\text { multipurpose } \\
\text { leguminous tree } \\
\text { species with arable } \\
\text { crop }\end{array}$ & $\begin{array}{l}\text { Conduct of livestock } \\
\text { survey }\end{array}$ & $\begin{array}{l}\text { Formulate affordable fish } \\
\text { feed for fish farmers }\end{array}$ \\
\hline & Irrigation practice & $\begin{array}{l}\text { Development of } \\
\text { cowpea and groundnut } \\
\text { varieties that are } \\
\text { resistant to aphid }\end{array}$ & $\begin{array}{l}\text { Development of } \\
\text { effective drugs and } \\
\text { vaccines for common } \\
\text { diseases }\end{array}$ & $\begin{array}{l}\text { Development of improved } \\
\text { method of controlling } \\
\text { hyacinth weeds }\end{array}$ \\
\hline \multirow[t]{2}{*}{2011} & $\begin{array}{l}\text { Adaptable Irrigation } \\
\text { Facilities }\end{array}$ & $\begin{array}{l}\text { Effect of Striga and } \\
\text { drought on crop } \\
\text { performance }\end{array}$ & $\begin{array}{l}\text { High mortality in } \\
\text { poultry }\end{array}$ & $\begin{array}{l}\text { Upgrading of Tilapia } \\
\text { Production }\end{array}$ \\
\hline & $\begin{array}{l}\text { Water potentials for } \\
\text { irrigation }\end{array}$ & $\begin{array}{l}\text { Production of woodlots } \\
\text { to meet world } \\
\text { standards }\end{array}$ & & $\begin{array}{l}\text { Fish feed formulation } \\
\text { from locally available raw } \\
\text { materials }\end{array}$ \\
\hline \multirow[t]{3}{*}{2012} & $\begin{array}{l}\text { Rain water harvesting } \\
\text { using available local } \\
\text { materials for } \\
\text { agricultural purposes }\end{array}$ & $\begin{array}{l}\text { Heat tolerant tomato, } \\
\text { Wheat varieties }\end{array}$ & $\begin{array}{l}\text { Genetic improvement } \\
\text { of local breads Cattle } \\
\text { and Sheep }\end{array}$ & $\begin{array}{l}\text { Fresh feed formulation } \\
\text { using locally available } \\
\text { materials }\end{array}$ \\
\hline & $\begin{array}{l}\text { Research on drip } \\
\text { irrigation to minimise } \\
\text { water losses through } \\
\text { evapotranspiration and } \\
\text { leaching }\end{array}$ & $\begin{array}{l}\text { High yielding maize } \\
\text { varieties that do with } \\
\text { less fertilizer and also } \\
\text { resistant to striga }\end{array}$ & $\begin{array}{l}\text { Pasture development } \\
\text { for ruminant animal } \\
\text { utilization }\end{array}$ & $\begin{array}{l}\text { Lack of fingerlings on fish } \\
\text { ponds }\end{array}$ \\
\hline & $\begin{array}{l}\text { Storage and } \\
\text { preservation of fruit } \\
\text { juice }\end{array}$ & $\begin{array}{l}\text { Cowpea variety that is } \\
\text { resistance to Striga }\end{array}$ & $\begin{array}{l}\text { Improvement on local } \\
\text { feed formulation for } \\
\text { efficient poultry } \\
\text { production }\end{array}$ & $\begin{array}{l}\text { Hypophysation of latex sp } \\
\text { gymnastic } s p\end{array}$ \\
\hline
\end{tabular}

Source: NAERLS and NPAFS (2010 - 2012) 
Table 3: North West problems that need research intervention between 2010 and 2012

\begin{tabular}{|c|c|c|c|c|}
\hline Year & $\begin{array}{l}\text { Agric Engineering } \\
\text { and Irrigation }\end{array}$ & Crop and Forestry & Livestock & Fisheries \\
\hline \multirow[t]{2}{*}{2010} & $\begin{array}{l}\text { Elimination of odour in } \\
\text { soymilk and flour }\end{array}$ & $\begin{array}{l}\text { Research on wild fruit } \\
\text { for economic } \\
\text { development }\end{array}$ & $\begin{array}{l}\text { Genetic improvement } \\
\text { for improved milk } \\
\text { quality and quantity }\end{array}$ & $\begin{array}{l}\text { Formulate affordable fish } \\
\text { feed for fish farmers }\end{array}$ \\
\hline & $\begin{array}{l}\text { Fabrication of low cost } \\
\text { processing equipment }\end{array}$ & $\begin{array}{l}\text { Development of } \\
\text { cowpea and groundnut } \\
\text { varieties that are } \\
\text { resistant to aphid }\end{array}$ & $\begin{array}{l}\text { Development of } \\
\text { effective drugs and } \\
\text { vaccines for common } \\
\text { diseases }\end{array}$ & $\begin{array}{l}\text { Development of improved } \\
\text { method of controlling } \\
\text { hyacinth weeds }\end{array}$ \\
\hline \multirow[t]{2}{*}{2011} & $\begin{array}{l}\text { Adaptable Irrigation } \\
\text { Facilities }\end{array}$ & $\begin{array}{l}\text { Intensify Research on } \\
\text { Moringa Olifera }\end{array}$ & High cost of feeds & $\begin{array}{l}\text { Formulation of floating } \\
\text { fish feeds locally. }\end{array}$ \\
\hline & $\begin{array}{l}\text { Water potentials for } \\
\text { irrigation }\end{array}$ & $\begin{array}{l}\text { Identification and } \\
\text { control of insects } \\
\text { causing powdery webs } \\
\text { in irrigated vegetables }\end{array}$ & $\begin{array}{l}\text { Use of indigenous } \\
\text { technologies in the } \\
\text { treatment of } \\
\text { dermaphilonsim } \\
\text { (Kirchi) in cattle. }\end{array}$ & $\begin{array}{l}\text { Species combination for } \\
\text { profit maximization }\end{array}$ \\
\hline \multirow[t]{4}{*}{2012} & $\begin{array}{l}\text { Simple and modern } \\
\text { technology }\end{array}$ & $\begin{array}{l}\text { Heat tolerant tomato } \\
\text { variety }\end{array}$ & $\begin{array}{l}\text { Development } \\
\text { improved breed and } \\
\text { upgrade of the local } \\
\text { breeds }\end{array}$ & $\begin{array}{l}\text { Feed formulation to } \\
\text { reduce cost of production } \\
\text { and maximize profit }\end{array}$ \\
\hline & $\begin{array}{l}\text { Underground water } \\
\text { monitoring for effective } \\
\text { utilization of } \\
\text { underground water } \\
\text { resources }\end{array}$ & $\begin{array}{l}\text { High yielding variety of } \\
\text { maize, rice, sorghum } \\
\text { and millet, }\end{array}$ & $\begin{array}{l}\text { Animal feeds and } \\
\text { feeding methods }\end{array}$ & $\begin{array}{l}\text { Improve hatchery } \\
\text { technology and sourcing } \\
\text { of good stock, improve } \\
\text { technology on fish farm } \\
\text { management }\end{array}$ \\
\hline & & $\begin{array}{l}\text { Improved agronomic } \\
\text { practices and the } \\
\text { Cereals and legumes } \\
\text { diseases and pest } \\
\text { control }\end{array}$ & $\begin{array}{l}\text { Feed formulation and } \\
\text { Nutrition }\end{array}$ & $\begin{array}{l}\text { Diseases control in fish } \\
\text { stock management }\end{array}$ \\
\hline & & $\begin{array}{l}\text { Problems of } \\
\text { nematodes insect } \\
\text { attack and pest, } \\
\text { diseases and drought } \\
\text { tolerant variety }\end{array}$ & $\begin{array}{l}\text { Tracing and } \\
\text { demarcation of } \\
\text { grazing facilities for a } \\
\text { more reward } \\
\text { livestock production } \\
\text { system and effective } \\
\text { diseases control }\end{array}$ & $\begin{array}{l}\text { Improve fish species and } \\
\text { medication }\end{array}$ \\
\hline
\end{tabular}

Source: NAERLS and NPAFS (2010 - 2012) 
Table 4: North Central problems that need research intervention between 2010 and 2012

\begin{tabular}{|c|c|c|c|c|}
\hline Year & $\begin{array}{l}\text { Agric Engineering } \\
\text { and Irrigation }\end{array}$ & Crop and Forestry & Livestock & Fisheries \\
\hline \multirow[t]{2}{*}{2010} & $\begin{array}{l}\text { Elimination of odour in } \\
\text { soymilk and flour }\end{array}$ & $\begin{array}{l}\text { Research on wild fruit } \\
\text { for economic } \\
\text { development }\end{array}$ & $\begin{array}{l}\text { Genetic improvement } \\
\text { for improved milk } \\
\text { quality and quantity }\end{array}$ & $\begin{array}{l}\text { Formulate affordable fish } \\
\text { feed for fish farmers }\end{array}$ \\
\hline & $\begin{array}{l}\text { Fabrication of low cost } \\
\text { processing equipment }\end{array}$ & $\begin{array}{l}\text { Development of } \\
\text { cowpea and groundnut } \\
\text { varieties that are } \\
\text { resistant to aphid }\end{array}$ & $\begin{array}{l}\text { Development of } \\
\text { effective drugs and } \\
\text { vaccines for common } \\
\text { diseases }\end{array}$ & $\begin{array}{l}\text { Development of improved } \\
\text { method of controlling } \\
\text { hyacinth weeds }\end{array}$ \\
\hline \multirow[t]{2}{*}{2011} & $\begin{array}{l}\text { Processing of shear nut } \\
\text { into oils and butter }\end{array}$ & $\begin{array}{l}\text { Control of fruit-fly in } \\
\text { mango. }\end{array}$ & High cost of feeds & $\begin{array}{l}\text { Addressing low yield of } \\
\text { fish in aquaculture }\end{array}$ \\
\hline & $\begin{array}{l}\text { Water potentials for } \\
\text { irrigation }\end{array}$ & $\begin{array}{l}\text { Identification and } \\
\text { control of insects } \\
\text { causing powdery webs } \\
\text { in irrigated vegetables }\end{array}$ & $\begin{array}{l}\text { Use of indigenous } \\
\text { technologies in the } \\
\text { treatment of } \\
\text { dermaphilonsim } \\
\text { (Kirchi) in cattle. }\end{array}$ & $\begin{array}{l}\text { How to make local fish } \\
\text { feed that floats }\end{array}$ \\
\hline \multirow[t]{4}{*}{2012} & $\begin{array}{l}\text { Fabrication of simple } \\
\text { farm tools }\end{array}$ & $\begin{array}{l}\text { Improved production } \\
\text { and storage of crops } \\
\text { especially tubers }\end{array}$ & $\begin{array}{l}\text { Development of local } \\
\text { drugs and vaccine for } \\
\text { poultry }\end{array}$ & $\begin{array}{l}\text { Economic analysis and } \\
\text { evaluation of local pellet } \\
\text { feeds and foreign floating } \\
\text { feeds on Claris sp. }\end{array}$ \\
\hline & $\begin{array}{l}\text { Efficient irrigation and } \\
\text { water management for } \\
\text { increasing crop } \\
\text { production }\end{array}$ & $\begin{array}{l}\text { Pest control on } \\
\text { cowpea at the peak of } \\
\text { rains }\end{array}$ & $\begin{array}{l}\text { Hatching of eggs } \\
\text { (chicken) using } \\
\text { kerosene incubator }\end{array}$ & $\begin{array}{l}\text { Composition of fish } \\
\text { production in an earthen } \\
\text { concrete and plastic } \\
\text { ponds }\end{array}$ \\
\hline & $\begin{array}{l}\text { Distribution of } 54 \text { units } \\
\text { of irrigation pumps to } \\
\text { dry season farmers }\end{array}$ & $\begin{array}{l}\text { Stem borer control in } \\
\text { maize and rice }\end{array}$ & $\begin{array}{l}\text { Use of indigenous } \\
\text { technology for the } \\
\text { treatment } \\
\text { dermatophilosin } \\
\text { (kirchi) in cattle as } \\
\text { compare to the use of } \\
\text { orthodox medicine }\end{array}$ & $\begin{array}{l}\text { Fish species combination } \\
\text { for profit maximization }\end{array}$ \\
\hline & $\begin{array}{l}\text { Improved juice making } \\
\text { technique }\end{array}$ & $\begin{array}{l}\text { Problem of premature } \\
\text { dropping of fruits such } \\
\text { as citrus, pawpaw and } \\
\text { mango }\end{array}$ & $\begin{array}{l}\text { Tracing and } \\
\text { demarcation of } \\
\text { grazing facilities for a } \\
\text { more reward } \\
\text { livestock production } \\
\text { system and effective } \\
\text { diseases control }\end{array}$ & $\begin{array}{l}\text { Improve fish species and } \\
\text { medication }\end{array}$ \\
\hline
\end{tabular}

Source: NAERLS and NPAFS (2010 - 2012) 


\section{Table 5: South West problems that need research intervention between 2010 and 2012}

\begin{tabular}{|c|c|c|c|c|}
\hline Year & $\begin{array}{l}\text { Agric Engineering } \\
\text { and Irrigation }\end{array}$ & Crop and Forestry & Livestock & Fisheries \\
\hline \multirow[t]{2}{*}{2010} & $\begin{array}{l}\text { Elimination of odour in } \\
\text { soymilk and flour }\end{array}$ & $\begin{array}{l}\text { Drought resistant } \\
\text { crops varieties }\end{array}$ & $\begin{array}{l}\text { Genetic improvement } \\
\text { for improved milk } \\
\text { quality and quantity }\end{array}$ & $\begin{array}{l}\text { Generation of fishery } \\
\text { data }\end{array}$ \\
\hline & $\begin{array}{l}\text { Fabrication of low cost } \\
\text { processing equipment }\end{array}$ & $\begin{array}{l}\text { Development of } \\
\text { cowpea and groundnut } \\
\text { varieties that are } \\
\text { resistant to aphid }\end{array}$ & $\begin{array}{l}\text { Development of } \\
\text { effective drugs and } \\
\text { vaccines for common } \\
\text { diseases }\end{array}$ & $\begin{array}{l}\text { Development of improved } \\
\text { method of controlling } \\
\text { hyacinth weeds }\end{array}$ \\
\hline \multirow[t]{2}{*}{2011} & Poor harvest storage & $\begin{array}{l}\text { Effective control of } \\
\text { diseases in } \\
\text { tomato(bacterial wilt) }\end{array}$ & High cost of feeds & Hatchery management. \\
\hline & $\begin{array}{l}\text { Water potentials for } \\
\text { irrigation }\end{array}$ & $\begin{array}{l}\text { Control of Bacterial } \\
\text { Blight in Tomatoes }\end{array}$ & Livestock census & $\begin{array}{l}\text { High cost of feeds in fish } \\
\text { farming }\end{array}$ \\
\hline \multirow[t]{5}{*}{2012} & $\begin{array}{l}\text { Mechanical processing } \\
\text { of locust bean }\end{array}$ & Processing equipment & $\begin{array}{l}\text { Prevention of catarrh } \\
\text { in small ruminants }\end{array}$ & $\begin{array}{l}\text { Fresh water culture fish } \\
\text { species }\end{array}$ \\
\hline & & $\begin{array}{l}\text { Expansion of cassava } \\
\text { based cuisine }\end{array}$ & $\begin{array}{l}\text { Effective control of } \\
\text { infection and } \\
\text { diseases }\end{array}$ & $\begin{array}{l}\text { Locally made floating } \\
\text { feed }\end{array}$ \\
\hline & $\begin{array}{l}\text { Improved processing } \\
\text { techniques of tomato } \\
\text { into paste }\end{array}$ & $\begin{array}{l}\text { Improved juice making } \\
\text { technique }\end{array}$ & $\begin{array}{l}\text { Alternative and cheap } \\
\text { energy ingredient in } \\
\text { animal and fish feeds }\end{array}$ & $\begin{array}{l}\text { Alternative to fish meal as } \\
\text { protein source }\end{array}$ \\
\hline & $\begin{array}{l}\text { Procurement of } \\
\text { irrigation pumps at low } \\
\text { price }\end{array}$ & $\begin{array}{l}\text { Determination of } \\
\text { planting time for } \\
\text { optimum yield of } \\
\text { plantain and banana }\end{array}$ & $\begin{array}{l}\text { Conversion of waste } \\
\text { into protein and } \\
\text { energy }\end{array}$ & $\begin{array}{l}\text { Diagnosis of fish } \\
\text { diseases }\end{array}$ \\
\hline & $\begin{array}{l}\text { Training on the use of } \\
\text { small scale irrigation } \\
\text { technique and } \\
\text { equipment }\end{array}$ & Processing equipment & $\begin{array}{l}\text { Prevention of catarrh } \\
\text { in small ruminants }\end{array}$ & $\begin{array}{l}\text { Fresh water culture fish } \\
\text { species }\end{array}$ \\
\hline
\end{tabular}

Source: NAERLS and NPAFS (2010 - 2012) 
Table 6: South South problems that need research intervention between 2010 and 2012

\begin{tabular}{|c|c|c|c|c|}
\hline Year & $\begin{array}{l}\text { Agric Engineering } \\
\text { and Irrigation }\end{array}$ & Crop and Forestry & Livestock & Fisheries \\
\hline \multirow[t]{2}{*}{2010} & $\begin{array}{l}\text { Fabrication of low cost } \\
\text { processing equipment. }\end{array}$ & $\begin{array}{l}\text { Fruit abortion in fruit } \\
\text { trees }\end{array}$ & $\begin{array}{l}\text { Development of } \\
\text { effective drugs and } \\
\text { vaccines for common } \\
\text { livestock diseases. }\end{array}$ & Hatchery management \\
\hline & $\begin{array}{l}\text { Preservation } \\
\text { techniques of some } \\
\text { foodstuffs }\end{array}$ & $\begin{array}{l}\text { Tuber mouth control in } \\
\text { cocoyam }\end{array}$ & $\begin{array}{l}\text { Genetic improvement } \\
\text { technologies in small } \\
\text { ruminants/poultry }\end{array}$ & \\
\hline 2011 & & $\begin{array}{l}\text { Storing of cassava } \\
\text { stems during floods } \\
\text { Use of local materials } \\
\text { for mushroom } \\
\text { production }\end{array}$ & $\begin{array}{l}\text { High mortality in } \\
\text { poultry }\end{array}$ & $\begin{array}{l}\text { Upgrading of Tilapia } \\
\text { Production } \\
\text { Fish feed formulation } \\
\text { from locally available raw } \\
\text { materials } \\
\text { statistical collection and } \\
\text { survey }\end{array}$ \\
\hline \multirow[t]{7}{*}{2012} & $\begin{array}{l}\text { General cost reduction } \\
\text { in irrigation engineering }\end{array}$ & $\begin{array}{l}\text { Development of } \\
\text { improved and } \\
\text { adaptable variety of } \\
\text { cocoyam }\end{array}$ & $\begin{array}{l}\text { Feed formulation for } \\
\text { livestock }\end{array}$ & $\begin{array}{l}\text { Cost effective feed } \\
\text { formulation for fisheries }\end{array}$ \\
\hline & $\begin{array}{l}\text { Modern technology in } \\
\text { post harvest } \\
\text { management }\end{array}$ & $\begin{array}{l}\text { Incidence of millipede } \\
\text { attack on cassava }\end{array}$ & $\begin{array}{l}\text { By-product of food } \\
\text { industry used for } \\
\text { production of } \\
\text { carbohydrate } \\
\text { component of } \\
\text { livestock feeds e.g. } \\
\text { yam and cassava } \\
\text { peel etc. }\end{array}$ & $\begin{array}{l}\text { Possibility of breeding } \\
\text { and stocking on brackish } \\
\text { water } \\
\text { Shrimps production } \\
\text { techniques in local ponds }\end{array}$ \\
\hline & $\begin{array}{l}\text { Storage of farm } \\
\text { produce }\end{array}$ & $\begin{array}{l}\text { Cocoyam } \\
\text { (colocasiaspp) } \\
\text { bacterial blight } \\
\text { diseases }\end{array}$ & $\begin{array}{l}\text { The use of cotton } \\
\text { seed to produce } \\
\text { animal feeds }\end{array}$ & $\begin{array}{l}\text { Lack of alternative fish to } \\
\text { catfish }\end{array}$ \\
\hline & $\begin{array}{l}\text { Modern technology in } \\
\text { post harvest } \\
\text { management }\end{array}$ & $\begin{array}{l}\text { Bettle attack on yam } \\
\text { tuber }\end{array}$ & $\begin{array}{l}\text { Crossing the sokoto } \\
\text { red with WAD }\end{array}$ & Control of fish diseases \\
\hline & $\begin{array}{l}\text { Storage and } \\
\text { preservation of fruit } \\
\text { juice }\end{array}$ & $\begin{array}{l}\text { Improve quality honey } \\
\text { bee keeping }\end{array}$ & $\begin{array}{l}\text { Improvement in small } \\
\text { ruminant breeding }\end{array}$ & $\begin{array}{l}\text { Fish feeds from local } \\
\text { sources, perinwinkle } \\
\text { production in fresh water, } \\
\text { local techniques for } \\
\text { tilapia sexing }\end{array}$ \\
\hline & & $\begin{array}{l}\text { Post harvest produce } \\
\text { management } \\
\text { Use of local materials } \\
\text { for mushroom } \\
\text { production }\end{array}$ & $\begin{array}{l}\text { Improvement in local } \\
\text { chicken breeding } \\
\text { In-breeding in small } \\
\text { ruminants }\end{array}$ & \\
\hline & & $\begin{array}{l}\text { Control of pest and } \\
\text { diseases especially for } \\
\text { tomato }\end{array}$ & & $\begin{array}{l}\text { local techniques for } \\
\text { tilapia sexing }\end{array}$ \\
\hline
\end{tabular}

Source: NAERLS and NPAFS (2010 - 2012) 
Table 7: South East problems that need research intervention between 2010 and 2012

\begin{tabular}{|c|c|c|c|c|}
\hline Year & $\begin{array}{l}\text { Agric Engineering } \\
\text { and Irrigation }\end{array}$ & $\begin{array}{l}\text { Crop and } \\
\text { Forestry }\end{array}$ & Livestock & Fisheries \\
\hline \multirow[t]{2}{*}{2010} & $\begin{array}{l}\text { Fabrication of low } \\
\text { cost processing } \\
\text { equipment. }\end{array}$ & $\begin{array}{l}\text { Fruit abortion in } \\
\text { fruit trees }\end{array}$ & $\begin{array}{l}\text { Development of } \\
\text { effective drugs } \\
\text { and vaccines for } \\
\text { common livestock } \\
\text { diseases. }\end{array}$ & $\begin{array}{l}\text { Hatchery } \\
\text { management }\end{array}$ \\
\hline & $\begin{array}{l}\text { Preservation } \\
\text { techniques of some } \\
\text { foodstuffs }\end{array}$ & $\begin{array}{l}\text { Tuber mouth } \\
\text { control in cocoyam }\end{array}$ & $\begin{array}{l}\text { Genetic } \\
\text { improvement } \\
\text { technologies in } \\
\text { small } \\
\text { ruminants/poultry }\end{array}$ & \\
\hline 2011 & & $\begin{array}{l}\text { Screening of } \\
\text { Cocoyam varieties } \\
\text { Use of local } \\
\text { materials for } \\
\text { mushroom } \\
\text { production }\end{array}$ & $\begin{array}{l}\text { High mortality in } \\
\text { poultry }\end{array}$ & $\begin{array}{l}\text { Upgrading of Tilapia } \\
\text { Production } \\
\text { Fish feed formulation } \\
\text { from locally available } \\
\text { raw materials } \\
\text { statistical collection } \\
\text { and survey }\end{array}$ \\
\hline \multirow[t]{3}{*}{2012} & $\begin{array}{l}\text { Using local material } \\
\text { to build irrigation } \\
\text { channel and pump } \\
\text { to cut cost of } \\
\text { installation }\end{array}$ & $\begin{array}{l}\text { Leaf curl and } \\
\text { shedding in pepper }\end{array}$ & $\begin{array}{l}\text { Using cheaper } \\
\text { material for } \\
\text { poultry feed } \\
\text { formulation }\end{array}$ & $\begin{array}{l}\text { Production floating } \\
\text { feed using locally } \\
\text { agricultural raw } \\
\text { materials. }\end{array}$ \\
\hline & $\begin{array}{l}\text { Massive erosion } \\
\text { problem and control }\end{array}$ & $\begin{array}{l}\text { Rice African } \\
\text { Gullmage }\end{array}$ & $\begin{array}{l}\text { Poultry, } \\
\text { Alternative to } \\
\text { compounded feed } \\
\text { to reduce cost }\end{array}$ & $\begin{array}{l}\text { Floating fish feed } \\
\text { production (Dryer) }\end{array}$ \\
\hline & $\begin{array}{l}\text { Locally adopted } \\
\text { fabricated tillage } \\
\text { machines }\end{array}$ & $\begin{array}{l}\text { Yam processing } \\
\text { and storage }\end{array}$ & $\begin{array}{l}\text { High cost of feed } \\
\text { and the need for } \\
\text { alternative } \\
\text { uses/substitutes }\end{array}$ & $\begin{array}{l}\text { Equipment for fish } \\
\text { processing }\end{array}$ \\
\hline
\end{tabular}

Source: NAERLS and NPAFS (2010 - 2012) 


\section{Conclusion and Recommendations}

It is inferred from this study that ADPs in Nigeria need training in various areas like SMSs, fish farming technology, seed production and certification, data collection and management, training courses etc. All categories of ADPs staff need training in one area or the other.

The study further revealed that the development of livestock feed formula from local materials, heat-tolerant and disease resistant varieties of tomato and wheat were the most pressing problems requiring the researches' intervention. It is recommended that ADPs should be given periodic training by relevant organizations on the identified areas and researchers should focus their researches more on the identified problems requiring research intervention. Moreover, state governments should adequately sponsor trainings of ADPs in their various states. This will strengthen the ADPs skills and increase their productivities for an effective extension service delivery in Nigeria. Lastly, it is recommended as suggested by NAERLS and NPFRA (2011) that all ADPs in Nigeria should embark on continuous advocacy for increased funding from states, establishment of collaborative and partnership linkages programmes which specifically favour training activities and diversifying their sources of income through direct revenue generation activities.

\section{References}

Allo, A.V. (2001). Professional requirements of the extension worker in training the extension worker. FFTC extension bulletin No. 173.

Ayansina, S. O. (2011). Farmers' Perception of Public and Private Extension Services in South Western Nigeria. A dissertation Submitted in Partial Fulfillment of the Requirements for the Award of Doctor of Philosophy in the Department of Agricultural Extension and Rural Development, Faculty of Agriculture of University of llorin.

Haruna, S. K. and Abdullahi, Y. M. G. (2013). Training of Public Extension Agents in Nigeria and the Implications for Government's Agricultural Transformation Agenda. Journal of Agricultural Extension Vol.17 (2) December, 2013 ISSN $1119-944 \mathrm{X}$

National Agricultural Extension and Research Liaison Services (NAERLS) and National Programme on Agriculture and Food Security (NPAFS) (2010). National report of Agricultural performance Survey of Wet Season in Nigeria. Pp $172-174$. ISBN: 978-978-912-360-5. 
National Agricultural Extension and Research Liaison Services (NAERLS) and National Programme on Agriculture and Food Security (NPAFS) (2011).National report of Agricultural performance survey of 2011 wet season in Nigeria. Pp $159-164$. ISBN: 978-978-919-060-7.

National Agricultural Extension and Research Liaison Services (NAERLS), (2012). National report of Agricultural performance survey of 2011 wet season in Nigeria. Pp 182 - 185. ISBN: 978-978-51085-6-9.

Ogunsumi L.O., Abegunde B. O. (2011). Evaluation of agricultural extension and delivery services in southwest Nigeria. International Journal of Agricultural Science Vol. 1(4): 581-591, September 2011 www.inacj.com ISSN: 2228-6322.

Sanni, A. O., Olowosegun, T., Sule, A. M., Muhammed, A., Yemi, I. Y. and Onimisi H. U (2009). Capacity Building and Training Requirement for Effective Fisheries and Aquaculture Extension in Nigeria - A Review. Journal of Nature and Science, 2009;7 (4), Pp $66-71$. ISSN 1545-0740. 